\title{
“Tagog” in The Community Environment of Java's Coastal Fishermen
}

\author{
Romadi $1^{1}$ \\ \{romadi@mail.unnes.ac.id ${ }^{1}$ \} \\ ${ }^{1}$ Universitas Negeri Semarang, Indonesia
}

\begin{abstract}
The lives of people on the Java Coast are rarely exposed in the context of social science studies in Indonesia, especially studies around the social life of the community. This paper aims to uncover the story of Tagog or Land Workers in the Environment of Javanese Coastal Fishermen. The research method used was qualitative with a case study design. The data sources of this study are informants, amounting to 20, divided into three categories, namely 10 Land Workers, 5 Fishermen, and 5 Communities outside the two. The results of this study can be explained that it has been known since the last 20 years, the activity of fishermen on Pedalen Beach has increased, both in terms of the number of fishermen and ships. Fishermen organize themselves by forming a cooperative called Mina Pawurni. In carrying out daily activities, Pedalen Beach fishermen experience environmental barriers, because the Java Coast is famous for its high waves. The social welfare of fishermen is also relatively low because the wages or fees given to Tagog are voluntary. Interestingly, Tagog also has an expression in art, Sintren is one of the folk arts that is the entertainment of Tagog. Besides having a high philosophy, Sintren reflects the life of Tagog on the Java Coast.
\end{abstract}

Keywords: Tagog, Environment, Sintren, Java Coast

\section{Introduction}

The story of Tagog in the study of social science in Indonesia is still rarely revealed. Tagog is found in Kebumen, precisely on Pedalen Beach. In the daily life of the Pedalen coastal fishing community, not all work can be done alone. Moreover, seeing the environmental conditions of Pedalen Beach, which is in the form of a coral reef, causes the ship to be unable to anchor to the shore properly. Even if the ship is moored on the shore, it is very dangerous, because it can be swayed by waves and hit the rock, so it breaks [1]. The existence of Tagog is not only about helping to anchor ships to the shore, but they also have a distinctive social life. This includes art expression. Tagog is very closely related to Sintren, a folk art that develops on the Java Coast, both north and south.

This study wants to describe the existence of Tagog while explaining their artistic expression in a social context. The contribution of this research is in the form of contributing ideas about the importance of social studies discussing the micro parts of the social life of the people in Indonesia. Social studies in Indonesia to this day still concentrate on something big, like politics and power. While the micro aspect is rarely noticed. This study wants to uncover this habit by presenting an academic text which is a micro social study. 


\section{Research Method}

This research was conducted using qualitative methods with case study design [2]. The case in this study is the life of Tagog, as a poor community on the coast of Java and the art activities they are involved in. The data sources of this study are informants, amounting to 20, divided into three categories, namely 10 Land Workers, 5 Fishermen, and 5 Communities outside the two. The object of this research observation is Tagog activity during work and social activities. This study uses a member check technique to see the truth of the data obtained [3]. Analysis of the data used is the Creswell model [4].

\section{Result and Discussion}

\subsection{Fishermen Community Environment}

According to Pranoto, coastal communities are a group of humans who live together inhabiting coastal areas, forming and having a culture that is typically associated with its dependence on coastal resources [5], [6]. Coastal communities are empowered unlike empowering other communities, because in coastal communities there are many community life groups, namely: 1) Capture fishing communities, namely a group of coastal communities whose main livelihood is fishing in the sea, which can be distinguished by type of equipment, namely modern fishing and traditional fishing fishermen; 2) collecting/basket fishing communities, namely coastal communities working around fish landing and auction sites, generally women; 3) labor fishing communities, which are the most common fishing groups in the life of coastal communities. Generally fishermen are poor laborers, so they do not have adequate capital and equipment for productive businesses; 4) Pond fishermen communities, namely fishermen who cultivate fish in ponds. To develop the lives of fishermen, Kusumastanto identifies factors that greatly affect coastal communities, namely 1) Fishermen are highly dependent on environment that is vulnerable to damage; 2) Fishermen are very dependent on the season; 3) Fishermen depend on the market; and 4) Fishermen are in a circle of poverty.

The condition of the fishing community which was also found in the fishermen of Pedalen Beach, Ayah District, Kebumen Regency, was actually not much different from other fishermen. Only geographically, Pantai Pedalen fishermen inhabit a village located in the mountains, so that it has an agrarian community environment. There are still many fishermen who have part-time jobs, for example as farmers, cattle or goat farmers, coconut collectors, and so on. That part-time job is often the savior of the family economy, when the fish famine [7].

Families belonging to the rich category, namely 3 plus prosperous 3 and prosperous families in Argopeni Village are Civil Servants, Soldiers, Police, village officials, entrepreneurs / shop owners, management of fishing/cooperative organizations and ship owners. The social structure of the Argopeni Village community places the rich as a respected group of people. Moreover, among the village officials and boat owners as well as people who have power among other communities, namely as administrators of Indonesian Fishermen Association (HNSI), Village Business Committee (KUD) administrators, and management of fishermen groups [8]. Indirectly fishermen in the Pedalen Coast area can be classified into three, namely the highest group are Soldiers, Police, Civil Servants, management of fishermen organizations, village officials, and boat owners, second group ship owners and crew, and third group namely fish basket, and Tagog. 
Fishermen who are considered to be the most respected groups are the management of fishermen organizations, which are generally held by boat owners, even to multiple positions, for example one person becomes Village Business Committee management, and is the manager of a group of fishermen. The boat owner is not only the owner of the ship, but has many ships, whose vessels can be rented or used by fishermen who do not have ships with a profit sharing system. Boat operators usually never go directly to sea fishing, because they are respected people, who usually have other jobs [9].

Sea fishermen are people who are active in fishing by boat. Even this group can still be divided into two, namely fishermen who have boats, and fishermen who do not have boats, but also go fishing for fish. When looking for fish in the sea, in one boat, it usually consists of boat owners and their workers, who generally still have close family ties. However, there is also a boat that has the same position, because the boat is the result of joint ventures in its purchase, or the results of renting together [10]. Or even in one boat has the same position because the boat belongs to a boat owner, which is used to sail with a profit sharing system. Meanwhile, fish traders are still grouped again into middlemen and sling fish traders.

The distributor is a large number of buyers of fish made through the auction process. From the results at Fish Auction (TPI), fish will be sold to a wider area, including outside Kebumen. However, there are also those sold to fish traders in Kebumen, including fish basket around the TPI location. While gendongan fish basket, have fish trading activities in the market around the village location, namely Ayah Market, Jetis Market, and Demangsari Market [11]. Tagog is a group of people whose jobs are lifting and pulling boats, removing and carrying outboard engines to storage locations, lifting nets to storage areas, and bringing fish catches to TPI. Among the Tagog jobs above, what is most often done is lifting and removing ships, because other work can be done by the fishermen themselves. Tagog in the structure of the fishing community, including the lowest group. They do not have working capital, other than labor and a plastic bucket.

\subsection{Tagog and Art Expressions of the Javanese Coastal Poor}

Environment Pedalen Beach is a rock niche, which means that the ship cannot anchor to the shore properly. Although the character of the fishing community is quite strong in conquering nature, but in this context the work of anchoring ships to the shore requires collaboration among elements of the workers. Even if the ship is moored on the shore, it is very dangerous, because it can be swayed by waves and hit the rocks, so it breaks. Moreover, the Pedalen Beach fishing boat is a special ship made of fiberglass [12] [13].

A special boat is a boat made of fibrous fiberglass, so the boat does not require connection between parts. Boats made from fiberglass are more expensive but strong and not easily broken by sea waves. Since the 1990s, fishermen have begun to use boats made of fiberglass. Boats made of wood are often easy to leak between wood joints, the more patched the easier it is to leak and endanger fishermen [14]. To anticipate the great south sea waves, more Pedalen Coast fishermen use boats made of fiberglass.

The advantage of using a fiberglass boat is lighter and not easy to leak, while the disadvantages, if the fiberglass boat has leaked, is difficult to repair. Fishing boats must be lifted to the shore, and carried away from the reach of the beach waves, the fishermen need the help of others. Well, people who help fishermen push the boat are Tagogs [15]. Tagog arises because of the needs of fishermen, because fishermen are unable to pull their own boats. To get rid of the ship, at least four Tagogs are needed to help together. Who is the Tagog? The 
people who become Tagogs are the neighbors of the fishermen themselves. They become Tagogs because they don't have other better job choices.

They cannot afford to rent a boat to find fish in the sea, they also do not have rice fields that can be cultivated to meet family needs, even if they have extensive rice fields that do not meet the needs of their families. Therefore, the job choice becomes Tagog. How about Tagog wages? Job as Tagog gets a salary according to the willingness of fishermen assisted [16], each Tagog is not exactly the same wage from the same fishermen, because with the model of "cawukan", that is some fish are taken without being graded. If the results of fishing fishermen get a lot of fish, then the Tagog wages will be a lot, but on the contrary if the results of fishing a little fishermen, then Tagog will get a little wage.

Between fishermen and Tagog already understand each other related to wages. To avoid a struggle between Tagogs, a Tagog group was formed, which indirectly regulates the Tagog system of work. In general, Tagog already understands the rules of turn to lift the boat, so that they do not scramble to lift the boat when a boat is about to land [17], [18]. In fact, each of them had a turn to carry out the work still collecting some fish to the group leader. After the fish are collected from the Tagogs on duty that day, the fish are then sold, and the money from the sale is saved as cash. Cash is used for mutual needs, especially social activities. This is done, because Tagog does not get a share of the results of the raman (fish auction results), unlike fishermen and fish baskets, which get the portion of the raman that is regulated and collected by the cooperative. Likewise regarding the famine funds, which were taken from the results of the raman, Tagog did not get a share.

Between fishermen and Tagog, they understand and understand each other with regard to wages. In order to avoid a fight between Tagogs, a Tagog group is formed, which indirectly regulates the Tagog work system. In general, Tagog already understands the rules of shifting a boat, so that it does not scramble to lift the boat if there are boats that will land. Even among them each got their turn to carry out the work, they still collected several fishes to the group leader [19]. After the fish are collected from the Tagog on duty that day, the fish is then sold, and the money from the sale is saved as cash. Cash is used for joint purposes, especially social activities. This is done, because Tagog does not get a share of the yield of raman (the result of a fish auction) [5], unlike fishermen and fish basket, which gets a share of raman arranged and collected by the cooperative. Likewise regarding famine funds, which are taken from the results of raman, Tagog does not get a share.

Socially Tagog is in the lowest order for coastal workers. Tagog's social life outside of work is no different from other societies, stay in touch with neighbors, attend religious events, take part in sporting activities, and also play arts like society in general [12], [20]. Tagog, being a unique society when there is an unusual expression of their art, when pop art spreads widely and tradition begins to weaken, Tagog naturally still maintains the existence of their arts, namely Sintren. An art which is an expression of the Javanese fishing community [21]. Currently the art enthusiasts come from low social class communities [13] [22], [23], Sintren is an art show that is rarely found today, but on the coast of Java there are still some community groups that preserve it [21], one of them is Tagog. Outside the Java Coast, Sintren can now only be enjoyed at certain moments such as large ceremonies or celebrations of people who have work in the village. Aside from being a means of entertainment for the community, Sintren's performance function is also used for the purposes of ritual ceremonies such as: village clean, sea alms, bala, nadzar, ruwatan, and marriage reject ceremony [7]. There can be no doubt that the cultural environment in which humans live greatly determines the form, form and level of human belief. Traditional humans generally carry out their cult activities with the intention of achieving a certain goal, or saying goodbye [25]. They always 
have a reason for justifying a cult, for example to prevent a woman's infertility, guarantee the fertility of the field, and ensure sufficient rain.

The explanation above shows ritual is an expression that is more logical than just psychological. The ritual shows the order of objects that are objectified. These symbols reveal behavior and feelings, and form the personal dispositions of devotees following their respective models [21]. Including Sintren, historically this art has indeed been born and developed among coastal communities, the birth of this art comes from the expression of women and beach workers not fishermen who are waiting for fishermen who are sailing in the middle of the ocean. This art reflects the deep desire of wives and other workers to embrace and provide services to fishermen who are generally men. Therefore, Sintren in general is shown at dusk when the sun is nearing drowning, because the Javanese people believe at that time the longing of the wives is reaching its peak. In addition to Sintren's art has developed into folklore, this shows that Sintren is a part of community identity that is important to be treated [26]-[28]. This social practice can still be witnessed in Tagog circles, Sintren art performances are usually held in the afternoon after they work. Their artistic expression is an expression of the life of coastal communities, who believe in God's grace and greatness, in addition to the compassion of their fellow humans.

\section{Conclusion}

Tagog is a land worker in a fishing community because it helps fishermen land ships. Therefore, the existence of Tagog is needed by fishermen, so also Tagog is very dependent on fishermen. The wages from Tagog depend on how much the fishermen give, and how many ships land. Such conditions place Tagog as a lower structure in the lives of fishermen in Pedalen Beach, Kebumen Regency. Behind that, Tagog is part of the Javanese cultural community, they live the traditional Sintren art with the aim of preserving the ancestral heritage. Synergy for coastal communities is an expression of life, art reflects the lives of people close to the sea. Tagog and Sintren are two cultural attributes that must be respected and seen as the identity of the people on the Java Coast.

\section{Acknowledgement}

This article is part of a special research on Sintren art and people on the Java Coast. The author dedicate this article for the Institute for Research and Community Service at Universitas Negeri Semarang which has funded this research.

\section{References}

s[1] M. Romadi, 'Sintren and Javanese Rural Community in Change', in International Conference on Rural Studies in Asia (ICoRSIA 2018), 2019.

[2] R. K. Yin, Case study research and applications: Design and methods. Sage publications, 2017.

[3] L. Harvey, 'Beyond member-checking: A dialogic approach to the research interview', Int. J. Res. Method Educ., vol. 38, no. 1, pp. 23-38, 2015. 
[4] J. A. Ollerenshaw and J. W. Creswell, 'Narrative research: A comparison of two restorying data analysis approaches', Qual. Inq., vol. 8, no. 3, pp. 329-347, 2002.

[5] H. D. Smith, 'The role of the social sciences in capacity building in ocean and coastal management', Ocean Coast. Manag., vol. 45, no. 9-10, pp. 573-582, 2002.

[6] I. L. Horowitz, 'Max Weber and the spirit of American sociology', Sociol. Q., vol. 5, no. 4, pp. 344-354, 1964.

[7] K. A'yun and Y. Kurrotaa, 'Sintren Sebuah Analisis Tembang dalam Kesenian Tradisional Sintren', PhD Thesis, FIB, 2009.

[8] T. Triyanto, S. Sumarwati, and K. Saddhono, 'Offering Ceremony "Sedekah Laut, In Central Java', in Proceeding of International Conference on Art, Language, and Culture, pp. 102-108.

[9] M. Jazuli, 'Map of Development of Central Java Coastal Dance', in 1st International Conference on Education Social Sciences and Humanities (ICESSHum 2019), 2019.

[10] W. W. Widjajanti, Antariksa, A. S. Leksono, and A. T. Subadyo, 'Socio-cultural studies to open space in fisherman settlement in Prigi, Trenggalek, East Java', in AIP Conference Proceedings, 2018, vol. 1977, p. 040005.

[11] D. Iswanto, 'Residing Tradition of Muslim Community in Java Northern Coastal', $J$. Archit. Des. Urban., vol. 1, no. 1, pp. 1-10, 2018.

[12] B. Agustine, 'Transmisi Kesenian Sintren Di Sanggar Sekar Pandan Keraton Kacirebonan', PhD Thesis, Universitas Pendidikan Indonesia, 2014.

[13] P. D. Darmoko, 'Kesenian Sintren dalam tarikan Tradisi dan Modernitas', Madaniyah, vol. 4, no. 1, 2016.

[14] R. Wessing, 'A community of spirits: people, ancestors, and nature spirits in Java', Crossroads Interdiscip. J. Southeast Asian Stud., vol. 18, no. 1, pp. 11-111, 2006.

[15] K. Graham and D. H. Spennemann, 'State emergency service local controllers' attitudes towards disaster planning for cultural heritage resources', Disaster Prev. Manag. Int. J., vol. 15, no. 5, pp. 742-762, 2006.

[16] E. Franke, 'The Religious Language of Objects: What Semar Says about the Religious Culture of Java', Mater. Relig. Cult. Tenri Univ.-Marburg Univ. Jt. Res. Proj., vol. 2, p. 109, 2017.

[17] S. Kullanda, 'The Lost Island Of Java', Sej. J. Dep. Hist., vol. 9, no. 9, 2017.

[18] A. B. Lapian, 'Sejarah Nusantara sejarah bahari', 1991.

[19] A. B. Lapian, Orang Laut, Bajak Laut, Raja Laut: Sejarah Kawasan Laut Sulawesi Abad XIX. Komunitas Bambu, 2009.

[20] P. D. Darmoko, 'Dekonstruksi Makna Simbolik Kesenian Sintren (Studi Kasus Pada Paguyuban Sintren Slamet Rahayu Dusun Sirau, Kelurahan Paduraksa, Kecamatan Pemalang, Kabupaten Pemalang)', PhD Thesis, UNS (Sebelas Maret University), 2013.

[21] D. Supardan, 'Sintren Art Show (The Analysis Of The Declining Of Historical Awareness Happening In The Coastal Border Of West Java And Central Java And Its Contribution To The History Learning)', Hist. J. Pendidik Dan Peneliti Sej., vol. 13, no. 1 , pp. 1-26.

[22] K. Foley, 'The dancer and the danced: Trance dance and theatrical performance in West Java', Asian Theatre J., vol. 2, no. 1, pp. 28-49, 1985.

[23] K. Foley, Essays on Southeast Asian performing arts: Local manifestations and crosscultural implications, vol. 18. Univ of California Intl \&, 1992. 
[24] E. Kismini, 'Preservation Of The Local Culture Values Through The Article Of Java Dance In Developing The National Character', in International Conference on Rural Studies in Asia (ICoRSIA 2018), 2019.

[25] M. Budianta, 'The dragon dance: Shifting meanings of Chineseness in Indonesia', in Asian and Pacific Cosmopolitans, Springer, 2007, pp. 169-189.

[26] R. Romadi and G. F. Kurniawan, 'Pembelajaran Sejarah Lokal Berbasis Folklore Untuk Menanamkan Nilai Kearifan Lokal Kepada Siswa', Sej. Dan Budaya J. Sej. Budaya Dan Pengajarannya, vol. 11, no. 1, pp. 79-94, 2017.

[27] C. B. Utomo and G. F. Kurniawan, 'Bilamana Tradisi Lisan Menjadi Media Pendidikan Ilmu Sosial di Masyarakat Gunungpati', Harmony, vol. 2, no. 2, pp. 169 184, 2017.

[28] M. Yanti, A. Cahyono, and S. Syakir, 'Sining Dance and Central Aceh Tourism', Catharsis, vol. 7, no. 2, pp. 326-332, 2018. 